\author{
Violetta Kwiatkowska-Wójcikiewicz"* \\ Józef Wójcikiewicz ***
}

\title{
ON TAKING DNA REFERENCE SAMPLES - COMMENT ON THE JUDGMENT OF THE EUROPEAN COURT OF HUMAN RIGHTS OF 14 APRIL 2020 IN THE CASE OF DRAGAN PETROVIĆ V. SERBIA, APPLICATION NO. 75229/10
}

\begin{abstract}
The comment deals with the evaluation of (not only) Serbian law concerning taking body samples for DNA examinations. The authors share the arguments of the dissenting opinion from the judgment in question that the phrase "other medical procedures" was at that stage sufficient for such a procedure. A comparative analysis of the Polish law is also conducted.
\end{abstract}

\section{Keywords}

reference DNA samples - DNA databases - retention of DNA profile - respect for private life - foreseeability of law

* Dr. hab., Professor, Department of Criminal Procedure and Criminalistics at the Nicolaus Copernicus University in Toruń, https://orcid.org/0000-0002-5074-2518, e-mail: vkd@law.umk.pl.

** Professor dr. hab., Head of the Department of Criminalistics at the Jagiellonian University in Kraków, https://orcid.org/0000-0001-7291-2074, jozef.wojcikiewicz@uj.edu.pl.

The authors wish to thank Professor Arkadiusz Lach for inspiration, and two anonymous reviewers for valuable remarks. 
DNA neither cares nor knows. DNA just is. And we dance to its music.

Subotica is a charming town located in the partly Hungarian-speaking province of Vojvodina in Serbia, that quite unexpectedly delights us with art nouveau artefacts just as in Gaudís atelier in Barcelona. Here, on 16 July 2008 a certain Mr A. informed the local police that he had heard from a certain Ms B. that she and Dragan Petrović, the later applicant, had taken part in a crime involving the severe beating of an elderly Mr C., which resulted in his death.

Following a series of requests and application on the part of the police and public prosecution, the investigating judge on 29 July ordered a search of Petrovićs apartment in order to find, in particular, a black leather jacket stolen from the victim, and to seize shoes for the purpose of conducting a trace evidence analysis. By means of a separate decision, the judge also ordered that a sample of the applicant's saliva be taken for a DNA analysis. The following day the applicant agreed to give the sample in the presence of his lawyer. However, the entire procedure was not recorded. Nevertheless, during the search, two handguns along with some ammunition were found. The DNA analysis gave yet a negative result.

Dragan Petrović lodged an appeal against the police conduct with regard to the collection of samples for DNA analysis and the conduct of the search in the context of his right to privacy, protected under Article 8 of the European Convention on Human Rights (ECHR), yet the Serbian Constitutional Court rejected the application.

The essence of both the application filed by Petrović and the analysis performed by the European Court of Human Rights were, in the context of the trial, forensic and genetic issues, covered by the provisions of the Code of Criminal Procedure (Zakonik o krivičnom postupku) of 2001. The then Article $131 \S \S 2$ and 3 allowed taking a blood sample and "other medical procedures" to be carried out forcibly. On the other hand, the code amended in 2011 in Article $140 \S \S 1,3$ and 4 and Article $142 \S 1$ has already expressis verbis regulated the procedure of taking buccal swab samples for the purposes of forensic genetic analysis. 
The Court found that in Article 131 there was no explicit reference to the collection of genetic reference samples, the phrase "other medical procedures" was insufficient and thus the violation of the applicant's privacy was not compliant with Article 8 Section 2 of the ECHR. As a result, the Court ruled, albeit not unanimously, that Article 8 in the context of DNA sampling had been violated. However, it also stated that there were no irregularities as far as the search of the apartment was concerned.

Stéphanie Mourou-Vikströmnoting wrote a dissenting opinion to this judgment stating that the judge in the case acted in full compliance with the law which, under the phrase "other medical procedures", covered the taking of DNA samples. In our opinion, she was right.

The legal analysis should be conducted ex ante, not ex post. The legislation concerning DNA samples has been evolving out of the development of the genetic method of human identification. When comparing the Serbian regulations with the Polish ones, it is to be concluded that the situation in Poland was quite similar. The first Polish expert opinions in forensic genetics were given in 1989, ${ }^{1}$ and the samples were taken on the basis of Article $65 \S 1$ Section 2 of the Code of Criminal Procedure passed in $1969 .^{2}$ Also, Article $74 \S 2$ Section 2 of the Code of Criminal Procedure of $1997^{3}$ did not explicitly regulate the collection of genetic reference samples (but these provisions were more effectively formulated than the Serbian ones), not to mention the fact that legal grounds for the use of direct coercion measures were absent as well. ${ }^{4}$ The 2004 amendment to the Criminal Code ${ }^{5}$ provided for the inclusion of Section 3 in Article 74, which obliges the accused to submit to the collection of a buccal swab that is carried out by a police officer, if it is necessary. By the way, in the judgment of 11 October 2016, court file ref. SK 28/15, the Constitutional Court ruled that this provision was compliant with Ar-

${ }^{1}$ Cf. J. Wójcikiewicz, “Ekspertyza genetyczna w Polsce - 20 lat później”, in V. Kwiatkowska-Wójcikiewicz (ed.) Kryminalistyka dla prawa - prawo dla kryminalistyki, Dom Organizatora TNOiK, 2010, pp. 93-94.

2 Dz.U. [Journal of Laws] of 1969, No. 13, Sec. 96.

${ }^{3}$ Dz.U. [Journal of Laws] of 1997, No. 89, Sec. 555.

${ }^{4} \mathrm{Cf}$. A. Lach, Granice badań oskarżonego w celach dowodowych. Studium w świetle reguty nemo se ipsum accusare tenetur i prawa do prywatności, Dom Organizatora TNOiK, 2010, pp. 150-180.

${ }^{5}$ Dz.U. [Journal of Laws] of 2005, No. 10, sec. 70. 
ticle 41 Section 1, Article 47 and Article 51 Section 2 in connection with Article 31 Section 3 of the Constitution. ${ }^{6}$

The problem still remains as to whether it is necessary to define specific forensic activities, e.g. taking a buccal swab, or whether it can be defined on a very general level, such as the aforementioned "other medical procedures", in which, in our opinion, the procedure of taking a buccal swab is included. We believe that a buccal swab is an uncomplicated procedure, which consists in rubbing the inside of the mouth with a suitable sterile throat spatula. There is no need to forcibly open the suspect's mouth, since it is enough to deflect the lower lip and rub the inside of it. These are non-invasive activities, they pose no risk to a person's physical or mental health, and do not take long. Undoubtedly, it should be emphasized that taking a buccal swab should be as little uncomfortable as possible. The need to collect tissue samples for examination and assessment is yet another issue.

In the case of DNA testing, there is a double interference with the right to privacy: sample taking and information autonomy. In the former case, taking a swab is not a serious interference. The situation is different in the context of sample and profile storage. In this situation, explicit regulation is required.

While in view of the discussed judgment of the Court, the current Polish regulations (Article 74 of the Code of Criminal Procedure, Article 15 Section 1 Subsection 3a of the Police Act) seem to be sufficiently precise, ${ }^{7}$ yet it is still problematic to say the same about Article 192a §1 of the Code of Criminal Procedure, which also provides for taking buccal swabs, saliva, and hair samples for genetic tests. The key problem here is the admissibility of using physical force and direct coercion measures.

According to $\S 3$ of Article 192a, tests and activities referred to in $\S 1$ shall be performed, respectively, in the conditions and in the manner specified in the regulations under Article $74 \S 4$ of the Code of Criminal Procedure, i.e. the regulation of the Minister of Justice of 23 February 2005 on submission to tests and performance of activities involv-

${ }^{6}$ J. Wójcikiewicz, V. Kwiatkowska-Wójcikiewicz, "The Constitutionality of Taking DNA Reference Sample”, Comparative Law Review, 2017, vol. 23, pp. 207-222.

7 Cf. K. Warecka, “Kiedy pobranie próbki DNA jest sprzeczne z Konwencją? Omówienie wyroku ETPC z dnia 14 kwietnia 2020 r., 75229/10 (Dragan Petrović)”, LEX/el. 2020. 
ing the accused and the suspect. ${ }^{8}$ Admittedly, in two subsections of this regulation - 5 and 10 - the possibility of using direct coercion measures was mentioned, but they expired on 20 March 2013 pursuant to the judgment of the Constitutional Court of 5 March 2013, ref. No. U 2/11. ${ }^{9}$ Therefore, and in the absence of an explicit permission to use direct coercion measures, the Minister's division of "witnesses"10 into those under Article $192 \S 4$ of the Code of Criminal Procedure, who must give their consent to the test, and those under Article 192a § 1 of the Code of Criminal Procedure, from whom buccal swabs and saliva and hair samples can be taken without their consent, ${ }^{11}$ is unlawful!

In examining the case of Dragan Petrović, the Court referred to two other DNA analysis-related cases, i.e., $S$ and Marper $v$. The United Kingdom $^{12}$ (2008) and the Caruana v. Malta case ${ }^{13}$ that was analyzed ten years later (2018). This first high-profile case was settled by the Grand Chamber. The Court ruled that retaining fingerprints, DNA samples and DNA profiles of suspected, yet not convicted persons, in the databases is incompliant with Article 8 of the ECHR. It should be stressed that this judgment has consequently reduced the British genetic database by about 1.5 million profiles!

The second case concerned the application of Romina Caruana, a resident of Qormi born in 1977. Romina's husband was charged with the homicide of his wife's lover. He was unlucky, because when having sexual relations with Romina in her house, while her husband was asleep, he accidentally stepped on a toy, which, unfortunately, woke her husband and led to a shooting some time after, as a result of which her lover died. On 10 may, a buccal swab from the applicant was taken. The

${ }^{8}$ Dz.U. [Journal of Laws] of 2005, No. 33, sec. 299.

9 Dz.U. [Journal of Laws] of 2013, sec. 375.

10 Article 192a refers to us, inhabitants of a storey, tenement, village, district, or town, and not to witnesses or suspects. Cf. J. Wójcikiewicz, Forensics and justice. Judicature on scientific evidence 1993-2008, Dom Organizatora TNOiK, 2009, p. 60.

11 Regulation of the Minister of Justice of 14 September 2020 on the notice of suspect's rights and duties in criminal proceedings, Dz.U. 2020, sec. 1620, subsec. 4. Cf. J. Wójcikiewicz, "Zakres podmiotowy art. 192a kodeksu postępowania karnego", Państwo i Prawo, 2016, Issue 8, pp. 96-101.

12 S. and Marper v. The United Kingdom, Applications nos. 30562/04 and 30566/04, Judgment of 4.12.2008.

13 Caruana v. Malta, Application no. 41079/16, Judgment of 15.05.2018. 
then law (Article 397 of the Criminal Code) enabled the court to order an investigation, inspection, experiment, and other undertakings necessary to investigate the case. A few years later, similarly to other countries, the wording of this provision was clarified by adding the phrase about taking DNA samples. The Court rejected Romina Caruana's application.

The case law initiated by the judgment in $S$. and Marper $v$. The United Kingdom, concerning the storage of, inter alia, DNA profiles, was continued by the Court in 2020 as in ruling on two further cases on 13 February: Gaughran v. The United Kingdom ${ }^{14}$ and Trajkovski and Chipovski v. North Macedonia. ${ }^{15}$

Fergus Gaughran was arrested by the police in 2008 for driving with excess alcohol. He was photographed at the police station and his fingerprints and a buccal swab were taken. He was fined $£ 50$ (GBP) and disqualified from driving for 12 months. Just two months after he pleaded guilty, he demanded the deletion of his personal data. His DNA sample was destroyed in 2015, but his DNA profile, fingerprints and the photograph were retained in the databases indefinitely.

The Court surveyed 31 members of the Council of Europe and found that the indefinite period of retention of profiles is allowed only in four countries; in twenty countries this period is limited in time, whereas in three countries a different policy was adopted. In four countries there are no relevant regulations pertaining to this issue. The Court emphasized the differences between fingerprints and DNA profiles, as the latter retain their informative value long after the donor's death, for example by making it possible to establish familial relationships. Consequently, the Court found that, with regard to biometric data, the retention period itself is not necessarily conclusive: the seriousness of the offence and safeguards available to the individual are also important. The absence of such factors disturbs the balance between public and personal interests, which, in the opinion of the Court, constitutes the violation of Article 8 of the ECHR.

In turn, the case from Macedonia concerned two thieves, from whom, after being arrested in 2010, DNA swabs were taken. The Court

${ }^{14}$ Gaughran v. The United Kingdom, Application no. 45245/15, Judgment of 13.02.2020.

15 Trajkovski and Chipovski v. North Macedonia, Applications nos. 53205/13 and 63320/13, Judgment of 13.02.2020. 
found that these actions had legal grounds in Article 14 of the Police Act authorizing the collection of "samples" to detect the offender. As in the Serbian case, the relevant provisions of the Police Act and the Code of Criminal Procedure were amended in 2012 and 2013, respectively, to explicitly refer to DNA analysis. However, the Court found that the statement specifying the period of profile retention (i.e., the data "may be retained until it has fulfilled the purpose for which it has been taken"), combined with the lack of adequate safeguards for the applicants' interests, upsets the balance between public and private interests, which consequently leads to the finding that there has been a violation of Article 8 of the ECHR. ${ }^{16}$

It seems legitimate to ask as to how the Court would rule when analysing an application of Jan Kowalski v. Poland, similar to the above mentioned ones.

If the reference sample was forcibly collected prior to 9 November 2013 , the Court would undoubtedly admit the violation of Article 8 of the ECHR, as it was only then that the amendment to the Code of Criminal Procedure came into force, pursuant to which (Article 1 Section 19) in Article 74 of the Code of Criminal Procedure Subsection 3a was added that constitutes the basis for the use of excessive force when sampling. ${ }^{17}$

As regards the sample retention period, the Polish regulations provided for two periods, depending on the nature and degree of social harm of the offence: up to 20 years and up to 35 years (Article 21d Section 1 and 2 of the Police Act). The authors of the 2018 amendment ${ }^{18}$ however, adopted a different framework (Article 58 Section 16): information, including personal data, is removed from the DNA data set, if the person concerned is over 100 years old or has died (Article 21e Section 2 Subsections $2 b$ and $c$ of the Police Act). If we consider the numerous safeguards for taking reference samples, and their processing and retention in a genetic database, it must be concluded that the Court would reject such an application de lege lata and it would do it unanimously!

${ }^{16}$ Ibid., paras 52-54.

17 Act of 27 September 2013 amending the Act - the Code of Criminal Procedure and other Acts, Dz.U. [Journal of Laws], sec. 1247.

18 Act of 14 December 2018 on Protection of Personal Data processed in relation to combating and preventing crime, Dz.U. [Journal of Laws] of 2019, sec. 125. 
